\title{
DEVELOPMENT OF THE QUANTITATIVE DETERMINATION METHOD FOR A NEW CARIES-PREVENTIVE COMPOUND
}

\author{
V.Yu.Anisimov, V.O.Gelmboldt, N.Yu.Bevz, V.A.Georgiyants \\ Odessa National Medical University \\ National University of Pharmacy
}

Key words: pharmaceutical analysis; quantitative determination; validation of the analytical method; cetylpyridinium hexafluorosilicate; caries-preventive agent

\begin{abstract}
Fluorides are the most important treatment and preventive additive in the composition of any form; they prevent development of caries by increasing the resistance of enamel, as well as production of acids by bacteria of dental plaque. At the Odessa National Medical University the work on searching for fluorine-containing compounds in a series of quaternary bases and their subsequent use in dentistry is conducted. The pharmacological studies have shown that "onium" hexafluorosilicates have a higher caries-preventive effectiveness compared to sodium fluoride. Cetylpyridinium hexafluorosilicate has been found to be the most active in the dose of $15 \mathrm{mg} / \mathrm{kg}$ when used in the form of oral applications of the gel; its mechanism of action is in activation of alkaline phosphatase and lysozyme of the pulp of the teeth. Development of reliable methods for identification and quantitative determination is a prerequisite for further use of this compound in medical practice. The aim of this work was to develop the method for quantitative determination of cetylpyridinium hexafluorosilicate. For further use of the method proposed for analysis of the compound under research its validation characteristics have been studied. According to the results of the research conducted it has been found that the method for quantitative determination of cetylpyridinium hexafluorosilicate in the substance corresponds to the following parameters: accuracy, precision, linearity $\left(\Delta_{z}=0.50 \leq \max \Delta_{z}=0.53, \delta=0.17 \leq \max \delta=0.32\right.$, $a=0.80 \leq \max a=1.60, r=1.0000 \geq \min r=0.9993)$.
\end{abstract}

Over the past decade there is a significant increase of affected teeth by caries in the population [8]. Caries is a disease, in which under the effect of bacteria the process of demineralization of teeth occurs. The risk of caries is associated with a number of causes, among them there is deficiency of fluorine in food and drinking water, which leads to brittleness and thinning of the enamel; the excess of carbohydrate food and sugar; dental plaque formed from decomposition of food debris; and it is also a stimulus for bacterial growth. In turn, excessive amounts of fluoride lead to binding of calcium salts in the inert calcium fluoride and the hepatotoxic action. Hexafluorosilicates $\left(\mathrm{SiF}_{6}\right)$ are one of the fixed forms of fluorine; moreover, they are almost completely free of drawbacks of fluorides [7]. In order to find substances with the cariesprotective and antibacterial properties the work on searching for new biologically active substances among hexafluorosilicate derivatives is conducted at the Odessa National Medical University [5, 6].

One of the most active compounds in this series is the salt of the quaternary base - cetylpyridinium hexafluorosilicate; development of methods of the quality control is the necessary condition for its further application. The basic physical and chemical properties of cetylpyridinium hexafluorosilicate have been studied, and the methods for its identification have been proposed [4].

Continuing the research on the standardization of the compound it was necessary to develop a method for its quantitative determination.

\section{Materials and Methods}

The experiments were carried out using the chromatographic grade sample of the compound (the content of impurities $-0.5 \%)$. During the work the measuring glassware of class A, reagents meeting the requirements of the State Pharmacopoeia of Ukraine (SPhU) and "AXIS" analytical balances were used.

The quantitative determination method. Dissolve $2.000 \mathrm{~g}$ in distilled water and dilute to $100.0 \mathrm{ml}$ with the same solvent. Transfer $25.0 \mathrm{ml}$ of the solution to a separating funnel, add $25 \mathrm{ml}$ of chloroform, $10 \mathrm{ml}$ of $0.1 \mathrm{M}$ sodium hydroxide and $10.0 \mathrm{ml}$ of a freshly prepared $50 \mathrm{~g} / 1$ solution of potassium iodide. Shake well, allow to separate the chloroform layer and discard chloroform extracts. To the aqueous layer add $40 \mathrm{ml}$ of hydrochloric acid, cool and titrate with $0.05 \mathrm{M}$ potassium iodate to a deepbrown colour that does not disappear. Add $2 \mathrm{ml}$ of chloroform and continue to titrate, shaking vigorously, until the chloroform layer no longer changes its colour. Simultaneously carry out the blank titration of a mixture of $10.0 \mathrm{ml}$ of the freshly prepared $50 \mathrm{~g} / 1$ solution of potassium iodide, $20 \mathrm{ml}$ of water and $40 \mathrm{ml}$ of hydrochloric acid.

One $\mathrm{ml}$ of $0.05 \mathrm{M}$ solution of potassium iodate corresponds to $37.56 \mathrm{mg}$ of $\left(\mathrm{C}_{21} \mathrm{H}_{38} \mathrm{~N}\right)_{2} \mathrm{SiF}_{6}$, which must be from $99.0 \%$ to $101.0 \%$.

\section{Results and Discussion}

Cetylpyridinium hexafluorosilicate is a quaternary ammonium salt, the residue of the pyridine cycle is in the basis of its structure. Cetylpyridinium hydrochloride is 


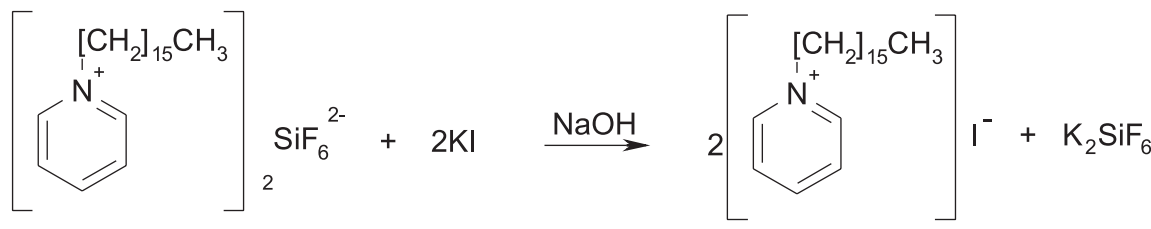

$2 \mathrm{KI}+\mathrm{KIO}_{3}+6 \mathrm{HCl} \rightarrow 3 \mathrm{ICl}+3 \mathrm{KCl}+3 \mathrm{H}_{2} \mathrm{O}$

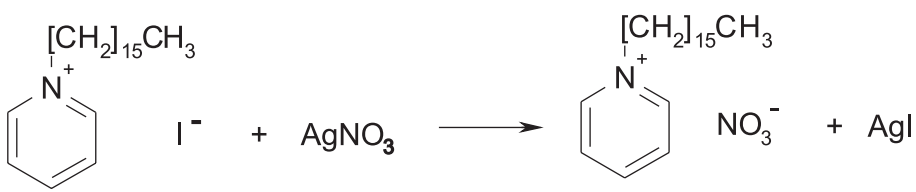

Accuracy and convergence of the results of quantitative determination

\begin{tabular}{|c|c|c|c|c|c|}
\hline $\begin{array}{l}\text { No. of the } \\
\text { model solution }\end{array}$ & $\begin{array}{c}\text { The substance } \\
\text { amount in the } \\
\text { sample }\end{array}$ & $\begin{array}{l}\text { Introduced in \% to } \\
\text { the concentration } \\
\text { of the reference } \\
\text { solution (Xiact\%) }\end{array}$ & $\begin{array}{c}\text { The volume of } 0.05 \\
\mathrm{M} \text { solution of } \mathrm{KIO}_{3 \prime} \\
\mathrm{V}, \mathrm{ml}(\mathrm{K}=1.0000)\end{array}$ & $\begin{array}{l}\text { Found in } \% \text { to the } \\
\text { concentration } \\
\text { of the reference } \\
\text { solution (Yi\%) } \\
\end{array}$ & $\begin{array}{l}\text { Found in } \% \text { to the } \\
\text { introduced } \\
\mathrm{Zi}=100(\mathrm{Yi} / \mathrm{Xi})\end{array}$ \\
\hline 1 & 0.1610 & 80.50 & 27.00 & 80.94 & 100.54 \\
\hline 2 & 0.1708 & 85.40 & 26.60 & 85.27 & 99.85 \\
\hline 3 & 0.1815 & 90.75 & 26.05 & 91.86 & 101.22 \\
\hline 4 & 0.1912 & 95.60 & 25.65 & 95.21 & 99.60 \\
\hline 5 & 0.2018 & 100.90 & 25.10 & 100.66 & 99.76 \\
\hline 6 & 0.2107 & 105.35 & 24.60 & 105.50 & 100.14 \\
\hline 7 & 0.2207 & 110.35 & 24.05 & 110.27 & 99.93 \\
\hline 8 & 0.2309 & 115.45 & 23.45 & 115.36 & 99.92 \\
\hline 9 & 0.2402 & 120.10 & 22.85 & 120.47 & 100.31 \\
\hline \multirow{2}{*}{\multicolumn{5}{|c|}{\begin{tabular}{r|} 
Mean, Z\% \\
Relative standard deviation, Sz\% \\
\end{tabular}}} & 100.14 \\
\hline & & & & & 0.50 \\
\hline \multicolumn{5}{|c|}{ Relative confidence interval $\Delta_{\mathrm{A}} \%=\mathrm{t}(95 \%, 7) \times \mathrm{Sz}$} & 0.53 \\
\hline \multicolumn{5}{|c|}{ Critical value for convergence of results $\Delta_{\mathrm{A}} \%$} & 1.00 \\
\hline \multicolumn{5}{|c|}{ Systematic error $\delta$} & 0.17 \\
\hline \multicolumn{5}{|c|}{$\begin{array}{r}\left.\text { Criterion of the systematic error insignificance 1) } \delta \leq \Delta_{A_{\mathrm{As}}}(\mathrm{g})^{\wedge} 0.5=0.33,2\right) \text { if not satisfied 1), } \\
\text { then } \delta \leq 0.33\end{array}$} & 0.32 \\
\hline \multicolumn{5}{|c|}{ The overall conclusion of the method } & correct \\
\hline
\end{tabular}

analogue by the structure of the compound studied. For its quantitative assessment the European and British Pharmacopoeias recommend to use the method of titration with potassium iodate after the appropriate sample preparation. First, the solution of potassium iodide in the alkaline medium was added, and the resulting compound was extracted with chloroform. The excess of potassium iodide in the aqueous layer was determined after acidifying the reaction mixture by titration with $0.05 \mathrm{M}$ solution of potassium iodate $[2,3]$.

We assumed that when adding potassium iodide cetylpyridinium hexafluorosilicate in the alkaline medium formed cetylpyridinium iodide having the properties of the ion associate and being well extracted with chloroform.

We consider that the reaction proceeds by the following mechanism (Scheme 1).

We confirmed that the reaction occurred by the exactly this mechanism in the following way. The chloro- form layer was carefully evaporated on a water bath to dryness, suspended with water, acidified by acetic acid diluted to a yellow-green colour with the bromphenol blue indicator. While thoroughly stirring the reaction mixture was titrated slowly with $0.1 \mathrm{M}$ solution of silver nitrate to an emerald-green colour. In the process of titration the precipitate was dissolved, and colloidal precipitate of silver iodide was gradually formed (Scheme 2).

Some validation characteristics of the method proposed for titration of the cetylpyridinium hexafluorosilicate substance with the indicator fixation of the titration end point were studied according to the requirements of the SPhU [1]. To validate the titration method the experimental batch of the substance was used. The loss on drying was $2.0 \%$. In calculations the content of the active substance was taken equal to $100 \%$.

To reduce uncertainty the titre of $0.05 \mathrm{M}$ potassium iodide solution was determined by the method of the SPhU [1]. 
The results of the linear dependence determination

\begin{tabular}{|c|c|c|c|}
\hline Parameters & Values & $\begin{array}{c}\text { Criteria (for tolerances } \\
99-101 \%, \mathrm{~g}=9 \text { ) }\end{array}$ & $\begin{array}{c}\text { Conclusion } \\
\text { (satisfied or not) }\end{array}$ \\
\hline $\mathrm{b}$ & 0.9931 & - & - \\
\hline $\mathrm{Sb}$ & 0.0091 & - & - \\
\hline $\mathrm{a}$ & 0.8016 & $\max \mathrm{a}=1.60$ & satisfied \\
\hline $\mathrm{Sa}$ & 0.9255 & - & - \\
\hline $\mathrm{So}$ & 0.3509 & $\max \mathrm{S}_{0}=0.53$ & satisfied \\
\hline $\mathrm{r}$ & 1.0000 & $\min \mathrm{r}=0.99926$ & satisfied \\
\hline $\mathrm{RSD}$ range & 13.5805 & - & - \\
\hline $\mathrm{Ro}$ & 0.9997 & - & - \\
\hline $\mathrm{Sb}^{2}$ & 0.0001 & - & - \\
\hline $\mathrm{Sa}^{2}$ & 0.8566 & - & \\
\hline$\delta_{R L, 80}=100 \cdot\left|\frac{a}{80}+(b-1)\right| \leq \frac{2}{3} \cdot \max \Delta_{A s} \leq 0.6600$ & 0.3308 & & \\
\hline$\delta_{R L, 120}=100 \cdot\left|\frac{a}{120}+(b-1)\right| \leq \frac{2}{3} \cdot \max \Delta_{A s} \leq 0.6600$ & 0.0031 & & \\
\hline $\mathrm{DL}$ & 3.0748 & & \\
\hline $\mathrm{LOQ}$ & 9.3193 & & \\
\hline
\end{tabular}

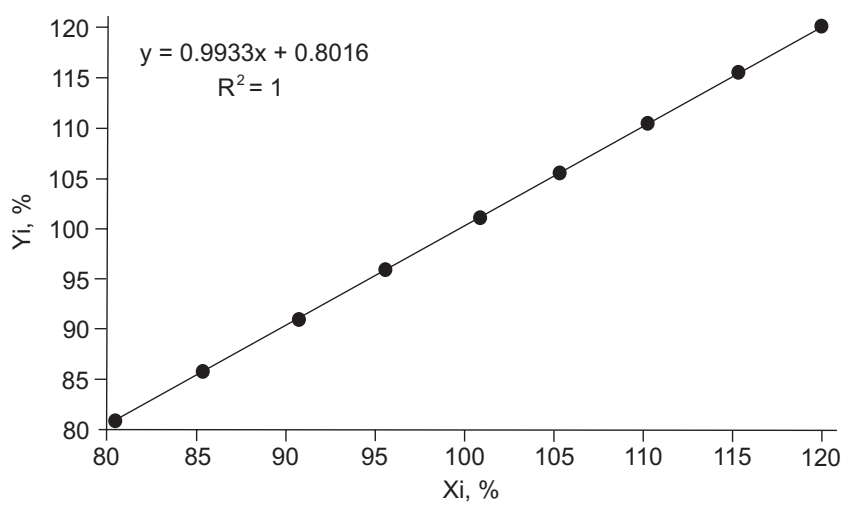

Fig. The linear dependence of $0.05 \mathrm{M}$ solution of potassium iodate on the concentration of the compound studied.

The mean value of 5 parallel titrations was obtained. The value of the correction factor to the nominal concentration of the titrated solution $K_{T}$ was 1.0000 with the relative standard deviation $R S D=0.10 \%$ and the confidence interval $\Delta$ (titr) $=0.10 \%$. Thus, the results of the titre determination $(\leq 0.2 \%)$ comply with the requirements of the SPhU for convergence [1].

The titration was carried out after adding a certain amount of potassium iodide solution, hydrochloric acid and chloroform; therefore, to reduce the error of titration it was appropriate to conduct the blank titration simultaneously.

To determine linearity the samples were taken for different points $(i)$ of the straight line, they were 80,85 , $90,95,100,105,110,115$ and $120 \%$ from the nominal weight of $200 \mathrm{mg}$. To study the reproducibility of the results for different experiments for studying linearity 5 samples for each point $(i)$ were taken (Tab. 1).
The results obtained were processed by the least squares method. The values $X_{i}, Y_{i}$ and $Z_{i}$ are given in Tab. 1 .

The results of the linear dependence processing by the least square method are given in Tab. 2 and Fig. As can be seen from Tab. 2, the requirement of simultaneous statistical insignificance of the values $|\mathrm{a}|$ and $|1-b|$ is performed for the set of 9 points; it meets the requirements of the practical acceptance of the linear dependence.

It should be noted that the systematic error value both by $80 \%$ of the nominal content $\left(\delta_{R L, 80}\right)$, and by $120 \%\left(\delta_{R L, 120}\right)$ does not exceed the maximal value (Tab. 2). The determination limit (DL) and limit of quantification (LOQ) do not exceed $32 \%$, i.e. they do not significantly affect the quantitative determination (Tab. 2).

From these calculations it is apparent that the maximum permitted value of the complete predicted uncertainty of the analytical procedure is more than the total calculated uncertainty of the method developed for quantitative determination of the active ingredient in the substance. Therefore, the method of redox titration can be used for quantitative determination of cetylpyridinium hexafluorosilicate with the tolerance of the active substance content of $\pm 1.0 \%$.

\section{CONCLUSIONS}

The method for quantitative determination of cetylpyridinium hexafluorosilicate in the substance has been developed using the redox method. When determining the basic validation characteristics of the method specified it has been found that the requirements for linearity, precision, accuracy are performed, and this method can be recommended for use. 


\section{REFERENCES}

1. Держсавна фармакопея України: в 3-х т. / Державне підприємство «Украйнський науковий фармакопейний центр якості лікарських засобів». - 2-е вид. - Х.: Держсавне підприємство «Украйнський науковий фармакопейний иентр якості лікарських засобів», 2015. - T. 1. - 1128 c.

2. British Pharmacopoeia [Електронний ресурс] / The British Pharmacopoeia Secretariat. - London, 2009. Vol. II. - Режсим достуny: https://www.vek-com.ru/78022.html.

3. European Pharmacopoeia 6th ed. - Strasbourg: European Directorate for the Quality of Medicines, 2008. Vol. 2. $-3308 p$.

4. Gelmboldt V.O., Anisimov V.Yu., Bevz N.Yu., Georgiyants V.A. // Der Pharma Chemica. - 2016. - Vol. 8, №1. - P. 169-173.

5. Gelmboldt V.O., Ganin Ed.V., Fonari M.S. et al. // J. Fluorine Chem. - 2009. - Vol. 130. - P. 428-433.

6. Gelmboldt V.O., Prodan O.V., Anisimov V.Yu. // Am. J. of Pharm. Tech. Res. -2014. - Vol. 4, № 6. - P. 513-521.

7. Lepsky V.V., Anisimov V.Yu., Lepsky V.V. // J. of Education, Health and sport. - 2015. - Vol. 5, №11. - P. 289-299.

8. Levitsky A.P., Gorokhivskiy V.N., Selivanskaya I.A. // Aktual'nye problemy transportnoy meditsiny. - 2014. Vol. 3, №37. - P. 136-139.

\section{РОЗРОБКА МЕТОДИКИ КІЛЬКІСНОГО ВИЗНАЧЕННЯ НОВОЇ КАРІЄС-ПРОФІЛАКТИЧНОЇ СПОЛУКИ \\ В.Ю.Анісімов, В.О.Гельмбольдт, Н.Ю.Бевз, В.А.Георгіяни}

Ключові слова: фрармацевтичний аналіз; кількісне визначення; валідація аналітичної методики; цетилпіридинію гексафрлуоросилікат; карієс-профрілактичний засіб

Флуориди є найважливішою лікувально-профрілактичної добавкою в складі будь-якої форми і запобігають розвитку карієсу, підвищуючи стійкість емалі, та перешкоджають виробленню кислот бактеріями зубного нальоту. У Одеському національному медичному університету проводиться робота з пошуку фрлуоровмісних сполук у ряду четвертинних основ з подальшим їх застосуванням у стоматології. Фармакологічні дослідження довели, що «онієві» гексафрлуоросилікати мають більш високу карієс-профрілактичну ефрективність в порівнянні з натрію фрлуоридом. Найбільш активним виявився цетилпіридинію гексафрлуоросилікат в дозі 15 мг/кг при використанні у вигляді оральних аплікацій гелю, механізм дії якого полягає в активації лужної фросфатази і лізоциму пульпи зубів. Для подальшого застосування сполуки в медичній практиці, необхідною умовою є розробка надійних методик його ідентифрікації та кількісного визначення. Метою роботи стала розробка методики кількісного визначення цетилпіридинію гексафрлуоросилікату. Для подальшого застосування запропонованої методики для аналізу досліджуваної сполуки, вивчали валідаційні характеристики. За результатами проведених досліджень встановлено, що методика кількісного визначення цетилпіридинію гексафллуоросилікату в субстанції відповідає за параметрами: правильність, прецизійність, лінійність $\left(\Delta_{z}=0.50 \leq \max \Delta_{z}=0.53, \delta=0.17 \leq \max \delta=0.32, a=0.80 \leq \max a=1.60, r=1.0000 \geq \min r=0.9993\right)$.

\section{РАЗРАБОТКА МЕТОДИКИ КОЛИЧЕСТВЕННОГО ОПРЕДЕЛЕНИЯ НОВОГО КАРИЕС-ПРОФИЛАКТИЧЕСКОГО СОЕДИНЕНИЯ \\ В.Ю.Анисимов, В.О.Гельмбольдт, Н.Ю.Бевз, В.А.Георгияни \\ Ключевые слова: фрармацевтический анализ; количественное определение;}

валидация аналитической методики; цетилпиридиния гексафоторосиликат;

кариес-профрилактическое средство

Фториды являются важнейшей лечебно-профрилактической добавкой в составе любой фрормы и предотвращают развитие кариеса, повышая стойкость эмали, и препятствуют выработке кислот бактериями зубного налета. В Одесском национальном медицинском университете проводится работа по поиску фрторсодержащих соединений в ряду четвертичных оснований с последующим их применением в стоматологии. Фармакологические исследования показали, что «ониевые» гексаффторосиликаты имеют более высокую кариес-профилактическую эфффективность по сравнению с натрия фрторидом. Наиболее активным оказался цетилпиридиния гексафтооросиликат в дозе 15 мг/ке при использовании в виде оральных аппликаций геля, механизм действия которого заключается в активации щелочной фросфратазы и лизоцима пульпы зубов. Для дальнейшего применения соединения в медицинской практике, необходимым условием является разработка надежных методик его идентифрикации и количественного определения. Целью работы стала разработка методики количественного определения цетилпиридиния гексафрторосиликата. Для дальнейшего использования предложенной методики для анализа исследуемого соединения, изучали валидационные характеристики. По результатам проведенных исследований установлено, что методика количественного определения цетилпиридиния гексафторосиликата в субстанции соответствует по параметрам: правильность, прецизионность, линейность $\left(\Delta_{z}=0.50 \leq m a x \Delta_{z}=0.53\right.$, $\delta=0.17 \leq \max \delta=0.32, a=0.80 \leq \max a=1.60, r=1.0000 \geq \min r=0.9993)$. 